\title{
Immunoglobulin Light Chain Levels Can Be Used to Determine Disease Stage in Children with Juvenile Idiopathic Arthritis
}

\section{NECIL KUTULCULER, NESLIHAN E KARACA, ELIF AZARSIZ, GUZIDE AKSU, NESRIN GULEZ}

OBJECTIVE: Patients with some inflammatory diseases have been shown to have increased levels of immunoglobulin light chains. In this study, we measured the concentrations of immunoglobulin kappa (к) and lambda $(\lambda)$ light chains in sera of patients with juvenile idiopathic arthritis (JIA) (study group), familial mediterranean fever (FMF) (disease control group) and in healthy children. Our aim was to compare immunoglobulin light chain levels with other wellknown markers of inflammation, such as the erythrocyte sedimentation rate (ESR) and the acute phase reactants (APRs), serum amyloid A (SAA) and Creactive protein $(\mathrm{CRP})$, to find out if immunoglobulin light chain determinations have any discriminating value in the follow-up of these patients.

RESULTS: ESR, CRP, SAA, $\mathrm{k}$ and $\lambda$ chain levels and $\lambda / \mathrm{IgG}$ ratio showed a statistically significant difference between active and remission stages in JIA patients. $\mathrm{k}$ correlated very well with SAA and ESR in both stages. On the other hand, $\lambda$ correlated with SAA and ESR only in the remission period. There was no significant difference in $\mathrm{k}$ and $\lambda$ chain levels between active and remission stages in FMF patients. In addition, $\mathrm{K}$ and $\lambda$ chain concentrations showed no correlation with other markers of inflammation and immunoglobulin levels neither in entire FMF group nor in different subgroups with respect to clinical status. Immunoglobulin light chains $\mathrm{K}$ and $\lambda$ as well as levels of three markers of inflammation were found to be significantly higher in JIA patients who were in the active stage of disease when compared to data of healthy children

CONCLUSION: Ig light chains especially $\mathrm{k}$ chain concentrations are helpful to determine disease stage in JIA patients but with our current data, they do not exhibit superiority to any of the classical tests for inflammation.

ABBREVIATIONS: ESR = erythrocyte sedimentation rate, $\mathrm{APRs}=$ acute phase reactants, $\mathrm{CRP}=\mathrm{C}$-reactive protein, $\mathrm{SAA}=$ serum amyloid-A, JIA $=$ juvenile idiopathic arthritis, FMF = familial mediterranean fever, $\mathrm{Ig}=$ immunoglobulin, ILAR = International League of Associations for Rheumatology

INDEX TERMS: Immunoglobulin light chains, acute phase reactants, chronic inflammatory disorders

Clin Lab Sci 2011;24(2):93

Necil Kutukculer, M.D., Ege University, School of Medicine, Division of Pediatric Immunology, Izmir, Turkey

Neslihan Edeer Karaca, M.D., Ege University, School of Medicine, Division of Pediatric Immunology, Izmir, Turkey

Elif Azarsiz, M.D., Ege University, School of Medicine, Division of Pediatric Immunology, Izmir, Turkey

Guzide Aksu, M.D., Ege University, School of Medicine, Division of Pediatric Immunology, Izmir, Turkey

Nesrin Gulez, M.D., Ege University, School of Medicine, Division of Pediatric Immunology, Izmir, Turkey

Address for Correspondence: Dr. Necil Kutukculer, Faculty of Medicine, Ege University, Department of Pediatrics, 35100 Bornova, Izmir, Turkey, Phone number:0090 232 3901016,necil.kutukculer@ege.edu.tr 


\section{RESEARCH AND REPORTS}

\section{INTRODUCTION}

Markers of inflammation such as erythrocyte sedimentation rate (ESR) and acute phase reactants (APRs) such as C-reactive protein (CRP) and serum amyloid-A (SAA) are widely used for laboratory and clinical assessments of patients who have an inflammatory rheumatic diseases. The ESR is a nonspecific measurement of increased serum proteins that occurs during inflammation. APRs are produced by the liver under regulation of circulating cytokines released by monocytes and macrophages. ${ }^{1}$

Immunoglobulins, produced by plasma cells and B lymphocytes, are built of two identical heavy and light chains and these light chains comprise one of two subtypes, known as kappa ( $\mathrm{k}$ ) and lambda $(\lambda) \cdot^{2-4}$ When the light chains are attached to the heavy chains, the light chains are referred to as bound light chains and when they are not attached to heavy chains they are called as free light chains. Normally, free light chains that are synthesized are quickly filtered out and/or catabolized by the kidneys.

Increased levels of monoclonal free light chains (called Bence-Jones proteins) have been measured as the consequence of clonal expansion of plasma cells. Many autoimmune and inflammatory diseases are accompanied with increased levels of oligoclonal free light chains in different body fluids. Polyclonal B cell hyperactivity, hypersecretion of antibodies and also increased local synthesis may be responsible for the increase in free light chain levels in relation to disease activity or relapses of disease..$^{5-11}$

As an inflammatory disease, JIA is the most common form of persistent arthritis in children that affects somewhere between $16-150$ of every 100,000 children and is characterized with morning stiffness, swelling of the affected joint(s), pain, limping and nonspecific flulike symptoms with respect to clinical type $(12,13)$. In a study including juvenile idiopathic arthtiris (JIA) patients, abnormalities in the peripheral B cell pool, namely kappa light chain repertoire were observed and the possibility of disturbance in B cell tolerance by multiple pathogenic mechanisms in JIA was highlighted. ${ }^{14}$ In Woulters et al's study, all JIA patients had hypergammaglobulinemia consistent with B cell hyperactivity. ${ }^{15}$

Familial mediterranean fever (FMF) is an autosomal recessively inherited disorder characterized by recurrent, inflammatory self limited episodes of fever and other symptoms. During the active stage of disease and fever attacks, there is a substantial influx of polymorphonuclear leukocytes into the affected tissues (16). Attack-free remission periods are accompanied by the up-regulation of neutrophil and monocyte phagocytic activity and oxidative burst. ${ }^{16}$

According to the recent literature, JIA and FMF have completely different pathogenic mechanisms in which $\mathrm{B}$ cells play an important role in the pathogenesis of JIA, but not in the pathogenesis of FMF. ${ }^{17}$ These facts led us to measure the concentrations of Ig kappa ( $\mathrm{K}$ ) and lambda $(\lambda)$ light chains in sera of patients with JIA (study group) and FMF (disease control group) and in healthy children (healthy control group) in order to compare them with other well-known markers of inflammation to find out if they have any discriminating value in the follow-up of these patients and if they correlate with classical markers of inflammation.

\section{PATIENTS and METHODS}

In this prospective study of two years duration (20082009), patients' sera were collected from the out-patient and in-patient clinics of Ege University Faculty of Medicine, Department of Pediatric Immunology, Izmir, Turkey. Parental informed consent was obtained and the study was performed in concordance with the Declaration of Helsinki ethical guidelines. A total of 117 patients (mean age: $11.3 \pm 4.0$ years, $54.7 \%$ were female and $45.3 \%$ were male) were included into the study. Eighty-two of the patients had JIA and 35 patients had FMF. Patients that followed up were included recurrently into the study which some of them were at different clinical stages. A total of 174 sera were collected from patients diagnosed with JIA $(\mathrm{n}=124$, $71.2 \%)$ and FMF ( $\mathrm{n}=50,28.8 \%)$. FMF patients were taken as a "disease-control group". JIA was defined as according to International League of Associations for Rheumatology (ILAR) classification ${ }^{18}$ and FMF patients were selected according to Tel-Hashomer criteria. ${ }^{19} \mathrm{~A}$ 


\section{RESEARCH AND REPORTS}

total of 30 age (11.6 3.26 years) and gender (16 male, 14 female) matched healthy children were included as a "healthy control group". These children had no chronic diseases and also no acute infections in the month prior to blood collection.

JIA patients who did not have fever, arthralgia, arthritis, rash or morning stiffness for at least three months were defined as "in remission" according to disease-specific international criteria. If the attack-free period was longer than three months in FMF patients, they were thought of as being "in remission" stage.

Ig kappa ( $\mathrm{K}$ ) and lambda ( $\lambda$ ) light chain levels were compared with other well-known markers of inflammation; namely ESR, SAA and CRP. The ESR was determined by the Westergreen method. C-reactive protein, serum amyloid $A, k$ and $\lambda$ chain concentrations and serum IgG, IgM levels were measured by nephelometry (with Dade Behring BNII Nephelometer Analyzer and commercially available kits by Dade Behring, Germany). The assay kit that was used, namely "antiserum against human immunoglobulin light chains", recognized ( $\kappa)$ and lambda $(\lambda)$ light chains both free and bound to heavy chains in intact immunoglobulins. Reference intervals are 1.7-3.7 g/L for $\mathrm{k}, 0.9-2.1 \mathrm{~g} / \mathrm{L}$ for $\lambda$ and $1.35-2.65$ for $\mathrm{k} / \lambda$. Reference curves were made up with multipoint calibration using $\mathrm{N}$ protein standard SL (Siemens, Dade Behring, Germany).

Statistical analyses were performed using Pearson correlation, Mann-Whitney U and Kruskal-Wallis test. A two-sided p-value less than 0.05 was considered to indicate statistical significance. Statistical analyses were performed by using SPSS (Windows Version 17.0, SPSS Inc., Chicago, IL).

\section{RESULTS}

Immunoglobulin light chain levels, ESR and APRs both in active and remission stages in JIA and FMF patients and in healthy controls were measured and are listed in Tables 1 and 2.

Table 1: Immunoglobulin light chain levels in patients with juvenile idiopathic arthritis, familial mediterranean fever and in healthy controls and their comparison with each other (Data are given as median (range); $<<0.01, \mathrm{p}<0.05$ : nonparametric tests).

\begin{tabular}{|c|c|c|c|c|c|c|c|}
\hline & $\begin{array}{l}\text { JIA } \\
\text { Active } \\
\text { (Group I) }\end{array}$ & $\begin{array}{l}\text { Remission } \\
\text { (Group II) }\end{array}$ & $\begin{array}{l}\text { FMF } \\
\text { Active } \\
\text { (Group III) }\end{array}$ & $\begin{array}{l}\text { Remission } \\
\text { (Group IV) }\end{array}$ & $\begin{array}{l}\text { Healthy } \\
\text { Control } \\
\text { (Group V) }\end{array}$ & $\begin{array}{l}* \\
\mathrm{P}<0.05\end{array}$ & $\mathrm{P}<0.01$ \\
\hline n (sera) & 69 & 55 & 11 & 39 & 30 & & \\
\hline Age & $\begin{array}{l}12 \\
(2-19)\end{array}$ & $\begin{array}{l}12 \\
(2-17)\end{array}$ & $\begin{array}{l}10 \\
(2-17)\end{array}$ & $\begin{array}{l}14 \\
(5-18)\end{array}$ & $\begin{array}{l}11 \\
(6-16)\end{array}$ & - & - \\
\hline K (g/L) & $\begin{array}{l}3.33 \\
(1.70-6.56)\end{array}$ & $\begin{array}{l}2.64 \\
(1.60-4.60)\end{array}$ & $\begin{array}{l}3.10 \\
(1.77-4.58)\end{array}$ & $\begin{array}{l}2.89 \\
(2.08-6.80)\end{array}$ & $\begin{array}{l}2.39 \\
(1.53-1.63)\end{array}$ & - & I-II, I-V \\
\hline$\lambda(\mathrm{g} / \mathrm{L})$ & $\begin{array}{l}1.94 \\
(0.4-10.7)\end{array}$ & $\begin{array}{l}1.47 \\
(0.90-2.65)\end{array}$ & $\begin{array}{l}1.98 \\
(0.9-4.02)\end{array}$ & $\begin{array}{l}1.66 \\
(0.85-3.70)\end{array}$ & $\begin{array}{l}1.40 \\
(0.85-2.55)\end{array}$ & - & I-II, I-V \\
\hline $\mathrm{k} / \lambda$ & $\begin{array}{l}1.76 \\
(0.16-5.25)\end{array}$ & $\begin{array}{l}1.77 \\
(1.08-2.67)\end{array}$ & $\begin{array}{l}1.68 \\
(1.11-2.44)\end{array}$ & $\begin{array}{l}1.74 \\
(1.17-3.13)\end{array}$ & $\begin{array}{l}1.62 \\
(1.27-1.97)\end{array}$ & - & - \\
\hline $\mathrm{k} / \mathrm{IgG}$ & $\begin{array}{l}0.22 \\
(0.14-0.43)\end{array}$ & $\begin{array}{l}0.22 \\
(0.14-0.33)\end{array}$ & $\begin{array}{l}0.21 \\
(0.16-0.39)\end{array}$ & $\begin{array}{l}0.20 \\
(0.15-1.11)\end{array}$ & $\begin{array}{l}0.22 \\
(0.20-0.28)\end{array}$ & - & - \\
\hline$\lambda / \operatorname{IgG}$ & $\begin{array}{l}0.14 \\
(0.12-0.92)\end{array}$ & $\begin{array}{l}0.12 \\
(0.08-0.20)\end{array}$ & $\begin{array}{l}0.14 \\
(0.09-0.35)\end{array}$ & $\begin{array}{l}0.11 \\
(0.09-0.60)\end{array}$ & $\begin{array}{l}0.13 \\
(0.11-0.16)\end{array}$ & I-II & - \\
\hline
\end{tabular}

In the JIA group, $55.7 \%(\mathrm{n}=69)$ of the sera were from patients with active JIA while $44.3 \%(n=55)$ of them were from patients in remission. Not only ESR $(\mathrm{p}<0.0001)$, CRP $(\mathrm{p}<0.0001)$ and SAA $(\mathrm{p}<0.0001)$ concentrations, but also $\mathrm{k}(\mathrm{p}<0.0001)$ and $\lambda(\mathrm{p}<0.0001)$ chain levels showed statistically significant differences between active and remission stages (Mann- Whitney $U$ test). The $\mathrm{k} / \lambda(\mathrm{p}=0.562)$ and $\mathrm{k} / \mathrm{IgG}(\mathrm{p}=0.391)$ ratios did not show any significant difference compared to different disease stages, but the $\lambda / \operatorname{IgG}(\mathrm{p}=0.025)$ ratio was significantly higher in the JIA with active disease group as compared to the JIA patients in remission. 
Table 2: Acute phase reactants in patients with juvenile idiopathic arthritis, familial mediterranean fever and in healthy controls and their comparison with each other. (Data are given as median (range); $\mathrm{p}<0.01, \mathrm{p}<0.05$ : nonparametric tests).

\begin{tabular}{|c|c|c|c|c|c|c|c|}
\hline & JIA & & FMF & & Healthy & $*$ & \\
\hline & $\begin{array}{l}\text { Active } \\
\text { (Group I) }\end{array}$ & $\begin{array}{l}\text { Remission } \\
\text { (Group II) }\end{array}$ & $\begin{array}{l}\text { Active } \\
\text { (Group III) }\end{array}$ & $\begin{array}{l}\text { Remission } \\
\text { (Group IV) }\end{array}$ & $\begin{array}{l}\text { Control } \\
\text { (Group V) }\end{array}$ & $\mathrm{P}<0.05$ & $\mathrm{P}<0.01$ \\
\hline $\begin{array}{l}\text { SAA } \\
(\mathrm{mg} / \mathrm{dL})\end{array}$ & $\begin{array}{l}177 \\
(3.10-1966)\end{array}$ & $\begin{array}{l}4.30 \\
(2.80-229)\end{array}$ & $\begin{array}{l}48.0 \\
(3-616)\end{array}$ & $\begin{array}{l}3.50 \\
(2.20-340)\end{array}$ & $\begin{array}{l}5.80 \\
(3.80-18.1)\end{array}$ & III-IV & $\begin{array}{l}\text { I-II, } \\
\text { I-V }\end{array}$ \\
\hline $\begin{array}{l}\text { CRP } \\
(\mathrm{mg} / \mathrm{dL})\end{array}$ & $\begin{array}{l}3.42 \\
(0.30-134)\end{array}$ & $\begin{array}{l}0.30 \\
(0.30-5.63)\end{array}$ & $\begin{array}{l}3.60 \\
(0.30-13.7)\end{array}$ & $\begin{array}{l}0.30 \\
(0.30-3)\end{array}$ & $\begin{array}{l}0.39 \\
(0.33-0.50)\end{array}$ & - & $\begin{array}{l}\text { I-II, } \\
\text { III-IV, } \\
\text { I-V }\end{array}$ \\
\hline $\begin{array}{l}\text { ESR } \\
(\mathrm{mm} / \mathrm{hr})\end{array}$ & $\begin{array}{l}42 \\
(12-140)\end{array}$ & $\begin{array}{l}12 \\
(4-41)\end{array}$ & $\begin{array}{l}46 \\
(30-100)\end{array}$ & $\begin{array}{l}12 \\
(2-72)\end{array}$ & $\begin{array}{l}10.5 \\
(4-20)\end{array}$ & - & $\begin{array}{l}\text { I-II, } \\
\text { III-IV, } \\
\text { I-V, } \\
\text { III-V }\end{array}$ \\
\hline
\end{tabular}

In the FMF group, $22.0 \%(\mathrm{n}=11)$ of the sera were from patients with active FMF while $78.0 \%(n=39)$ of them were from patients in remission (Table-1). Although a significant increase was found in ESR ( $\mathrm{p}=0.012)$, CRP $(\mathrm{p}<0.0001)$ and SAA $(\mathrm{p}<0.0001)$ levels in patients in the active disease group, there was no significant difference in $\mathrm{k}(\mathrm{p}=0.981)$ and $\lambda(\mathrm{p}=0.535)$ chain levels, $\mathrm{k} / \lambda$ ratio $(\mathrm{p}=0.419), \mathrm{k} / \mathrm{IgG} \quad(\mathrm{p}=0.896)$ and $\lambda / \operatorname{IgG}$ $(\mathrm{p}=0.896)$ between active and remission periods of FMF patients (Mann- Whitney $U$ test). In addition, in the FMF group, $\mathrm{k}$ and $\lambda$ chain concentrations correlated $(\mathrm{p}<0.0001, \mathrm{r}=0.766)$ only with each other and showed no correlation with ESR, APRs and immunoglobulin concentrations neither in entire FMF patients nor with respect to clinical stages.

Correlations of $\mathrm{Ig}$ light chains and inflammatory markers in JIA patients with respect to clinical stages are shown in Table-3 (Pearson correlation). We found that $\kappa$ chain levels correlated very well with SAA and ESR in both stages. On the other hand, $\lambda$ chain levels correlated with SAA and ESR only in the remission period. No correlation was observed between Ig light chain levels and CRP.

We also evaluated Ig light chain concentrations with respect to immunoglobulin levels. There was no significant difference between three immunoglobulin level (low, medium, high) group (Kruskal Wallis test).
Twelve patients had very high IgG levels $(1893 \pm 821$ $\mathrm{mg} / \mathrm{dl}$ ) when compared to age matched healthy children $(1051 \pm 228 \mathrm{mg} / \mathrm{dl})$ and $\mathrm{k}(\mathrm{p}=0.031)$ and $\lambda(\mathrm{p}=0.006)$ light chain concentrations showed statistically significant relationship with high IgG concentrations in sera of these patients. $\mathrm{K}$ levels positively correlated with $\operatorname{IgG}(\mathrm{p}=0.009, \mathrm{r}=0.611)$ and $\operatorname{IgM}(\mathrm{p}=0.041, \mathrm{r}=0.500)$ in JIA patients who were in the active stage of disease. In remission period, there was no correlation between light chains and immunoglobulins (pearson correlation).

Table 3: Correlation of Ig light chains and acute phase reactants in juvenile idiopathic arthritis patient group with respect to clinical stages.

\begin{tabular}{lllll}
\hline \multirow{2}{*}{ active } & SAA & ESR & CRP \\
& & $\mathrm{p}=0.012^{* *}$ & $\mathrm{p}=0.006^{*}$ & $\mathrm{p}=0.682$ \\
& $\mathrm{r}=0.301$ & $\mathrm{r}=0.336$ & $\mathrm{r}=0.058$ \\
& $\mathrm{p}=0.019^{* *}$ & $\mathrm{p}=0.004^{*}$ & $\mathrm{p}=0.269$ \\
\multirow{3}{*}{ remission } & $\mathrm{r}=0.315$ & $\mathrm{r}=0.383$ & $\mathrm{r}=0.161$ \\
& & $\mathrm{r}=0.321$ & $\mathrm{p}=0.174$ & $\mathrm{p}=0.656$ \\
& \multirow{2}{*}{ active } & $\mathrm{r}=0.140$ & $\mathrm{r}=0.195$ & $\mathrm{r}=-0.064$ \\
& & $\mathrm{p}=0.027^{* *}$ & $\mathrm{p}=0.002^{*}$ & $\mathrm{p}=0.264$ \\
& & $\mathrm{r}=0.298$ & $\mathrm{r}=0.403$ & $\mathrm{r}=0.163$
\end{tabular}

${ }^{*} \mathrm{p}<0.01,{ }^{* *} \mathrm{p}<0.05$ (bivariate pearson correlation)

Immunoglobulin light chains $\mathrm{K}$ and $\lambda$ as well as three classical markers of inflammation were found to be significantly high in JIA patients who were in the active stage of disease when compared to data of healthy children and to JIA patients who were in remission 


\section{RESEARCH AND REPORTS}

(Table 1 and 2 ). On the other hand, $\mathrm{k} / \lambda$ ratio, $\mathrm{k} / \mathrm{IgG}$ and $\lambda / \mathrm{IgG}$ did not show any significant difference between four different patient subgroups and healthy controls (Table 1).

Active and remission stage specimens from the same JIA patients (27 samples from 13 patients) were examined and we observed that ESR $(\mathrm{p}=0.001)$, SAA $(\mathrm{p}<0.0001)$ and CRP $(\mathrm{p}<0.0001)$ levels differed significantly with respect to disease activity. There was a decrease in $\mathrm{K}$ and $\lambda$ levels in remission period, but there was not statistically significant difference $(\mathrm{p}=0.114$ for $\mathrm{K}$, $\mathrm{p}=0.511$ for $\lambda$ ) between both clinical stages which could be related to small sample size.

\section{DISCUSSION}

Previously, relevance of increased Ig light chain concentrations in the pathogenesis of some chronic inflammatory disorders such as systemic lupus erythematosus or Sjögren's syndrome was previously reported. ${ }^{11,20}$ Low et $\mathrm{al}^{21}$ assessed $\mathrm{B}$ cell activity by measuring the amount of and $k / \lambda$ ratio in circulating immune complexes from the sera of patients with JIA and they showed preferential selection of lambda chains contributing to the formation of pathogenic circulating immune complexes. In addition, they also concluded that a reversal of the normal $\kappa / \lambda$ ratio in JIA circulating immune complexes may be used as a marker for increased B cell activity. ${ }^{21}$ In the study by Morbach et $\mathrm{al}^{14}$ related with the role of light chains in JIA pathogenesis, no clear evidence was found out.

Sensitive nephelometric assays for free $\mathrm{K}$ and $\lambda$ chains are more effective in detecting conditions where only monoclonal light chains are produced (light chain disease or amyloidosis) or where there is minimal secretion of intact immunoglobulins (non-secretory or oligosecretory multiple myeloma). Hypergammaglobulinemia and musculoskeletal manifestations are common findings in both JIA and FMF even though these diseases have different pathogenesis. Therefore, in the light of above findings, we chose to measure the levels of free and bound light chains together in addition to well-known APRs and serum immunoglobulins.
Arthritis may be the initial or sole feature of FMF. Asymmetric arthritis in larger joints of the lower extremity is most typical for FMF and very similar to arthritis observed in JIA. However, the diversity and the nonspecifity of the various clinical manifestations of FMF can obscure the diagnosis. In the comparison of pathogenesis between these two inflammatory disorders, neutrophils were found to play a more important role than $\mathrm{B}$ cells in the pathogenesis of FMF. ${ }^{22}$ Therefore, light chain shedding is not expected in FMF patients although hypergammaglobulinemia is often observed. In this study, $\mathrm{k}$ and $\lambda$ chain concentrations correlated with each other but not with other inflammatory markers in samples taken from FMF patients in acute and remission stages. In addition, a significant increase was found in ESR, CRP and SAA levels in the active FMF group as compared to the FMF patients in remission, while there was no significant difference in $\mathrm{K}$ and $\lambda$ chain levels between active and remission periods. $\mathrm{K}$ and $\lambda$ chain levels of both active and remission stage FMF patients also did not differ from levels measured in healthy controls. Therefore, FMF patient samples served as a good disease control group with no observation of increased light chain levels in relation to clinical stage.

The ESR, CRP, SAA and Ig light chain levels showed a statistically significant difference between JIA patients in active and remission stages of disease. $\mathrm{k}$ levels showed better correlation with ESR and SAA than $\lambda$ levels and it was thought that Ig light chain levels, especially $\mathrm{K}$ chain, were good markers for detecting disease stage in JIA patients.

In chronic inflammatory disorders, $\mathrm{B}$ cells can contribute to tissue damage by autoantibody production and presentation of antigens to $T$ cells. Corcione et $\mathrm{al}^{23}$ demonstrated an expansion of activated switch memory $\mathrm{B}$ cells and of IgG-secreting plasmablasts in the synovial fluid from JIA patients. This finding is an evidence of long term immune stimulation. Long-term stimulation of immune system leads an increase in IgG levels as often observed in JIA. In our study, $\mathrm{K}$ and $\lambda$ light chain concentrations were not correlated with whole IgG levels and correlated only in a group of sera with very high $\operatorname{IgG}$ concentrations 


\section{RESEARCH AND REPORTS}

suggesting to us that simply measuring total immunoglobulins is not always helpful to determine disease stage.

Increased concentrations of immunoglobulin light chains might be an indicator of B cell hyperactivity thereby reflecting disease activity better than other inflammation parameters when B cell involvement is suspected in the pathogenesis. As a result, Ig light chains especially $\mathrm{K}$ chain concentrations are helpful to determine disease stage in JIA patients but with our current data, they do not exhibit superiority to any of the well-known tests for inflammation.

\section{REFERENCES}

1. Breda L, Nozzi M, De Sanctis S, Chiarelli F. Laboratory tests in the diagnosis and follow-up of pediatric rheumatic diseases: an update. Semin Arthritis Rheum 2010;40(1):53-72.

2. Skvortsov VT, Gurvich AK. Relative rates of synthesis of immunoglobulins and light chains in rabbit spleen cells during secondary response. Nature 1968;218:377-8.

3. Hopper JE, Papagiannes E. Evidence by radioimmunoassay that mitogen-activated human blood mononuclear cells secrete significant amounts of light chain Ig unassociated with heavy chain. Cell Immunol 1986;101:122-31

4. Bradwell AR, Carr-Smith HD, Mead GP, Tang LX, Showell PJ, Drayson MT, et al. Highly sensitive, automated immunoassay for immunoglobulin free light chains in serum and urine. Clin Chem 2001;47:673-80.

5. Van der Heijden M, Kraneveld A, Redegeld F. Free immunoglobulin light chains as target in the treatment of chronic inflammatory diseases. Eur J Pharmacol 2006;533:31926.

6. Thio M, Blokhuis BR, Nijkamp FP, Redegeld FA. Free immunoglobulin light chains: a novel target in the therapy of inflammatory diseases. Trends Pharmacol Sci 2008;29:170-4.

7. Solling K, Solling J, Romer FK. Free light chains of immunoglobulins in serum from patients with rheumatoid arthritis, sarcoidosis, chronic infections and pulmonary cancer. Acta Med Scand 1981;209:473-7.

8. Cooper A, Bluestone R. Free immunoglobulin light chains in connective tissue disease. Ann Rheum Dis 1968;27:537-43.

9. Katzmann JA, Abraham RS, Dispenzieri A, Lust JA, Kyle RA. Diagnostic performance of quantitative kappa and lambda free light chain assays in clinical practice. Clin Chem 2005;51:87881.
10. Hopper JE, Golbus J, Meyer C, Ferrer GA. Urine free light chains in SLE: clonal markers of B-cell activity and potential link to in vivo secreted Ig. J Clin Immunol 2000;20:123-37.

11. Presslauer S, Milosavljevic D, Brücke T, Bayer P, Hübl W. Elevated levels of kappa free light chains in CSF support the diagnosis of multiple sclerosis. J Neurol 2008;255:1508-14.

12. Ravelli A, Martini A. Juvenile idiopathic arthritis. Lancet 2007, 369(9563):767-8

13. Feldman DE, Bernatsky S, Houde M. The incidence of juvenile rheumatoid arthritis in Quebec: a population databased study. Pediatr Rheumatol Online J 2009;7:20

14. Morbach H, Richl P, Faber C, Singh SK, Girschick HJ. The kappa immunoglobulin light chain repertoire of peripheral blood B cells in patients with juvenile rheumatoid arthritis. Molecular Immunology 2008;45:3840-6

15. Woulters $\mathrm{CH}$, Ceuppens JL, Stevens EA. Different circulating lymphocyte profiles in patients with different subtypes of juvenile idiopathic arthritis. Clin Exp Rheumatol 2002;20:23948.

16. Kirkali G, Tunca $M$, Genc S, Jaruga P, Dizdaroglu $M$. Oxidative DNA damage in polymorphonuclear leukocytes of patients with familial Mediterranean fever. Free Radic Biol Med 2008;144:386-93.

17. Morbach H, Girchiek H. Do B cells play a role in the pathogenesis of juvenile idiopathic arthritis? Autoimmunity 2009;42:373-5.

18. Petty RE, Southwood TR, Manners P, Baum J, Glass DN, Goldenberg $\mathrm{J}$, et al. International League of Associations for Rheumatology classification of juvenile idiopathic arthritis: second revision, Edmonton, 2001. J Rheumatol 2004;31:3902.

19. Livneh A, Langevitz P, Zemer D, Zaks N, Kees S, Lidar T. Criteria for the diagnosis of familial mediterranian fever. Arthritis Rheum 1997, 40:1879-85.

20. Redegeld FA, Van der Heijden MW, Kool M, Heijdra BM, Garssen J, Kraneveld AD, et al. Immunoglobulin-free light chains elicit immediate hypersensitivity-like responses. Nat Med 2002;8:694-701.

21. Low JM, Chauhan AK, Moore TL. Abnormal kappa: lambda light chain ratio in circulating immune complexes as a marker for B cell activity in juvenile idiopathic arthritis. Scand J Immunol 2007;65:76-83.

22. Onen F.Familial mediterranian fever (review). Rheumatol Int 2006, 26:489-96.

23. Corcione A, Ferlito F, Gattorno M, Gregorio A, Pistorio A, Gastaldi R, et al. Phenotypic ana functional characterization of switch memory B cells from patients with oligoarthriculer juvenile idiopathic arthritis. Arthritis Res Ther 2009;11:R150. 